\title{
Gastric Dilatation-Volvulus Syndrome: Outcome and Factors Associated with Perioperative Mortality
}

\author{
J. ZATLOUKAL ${ }^{1}$, M. CRHA ${ }^{2}$, L. LEXMAULOVÁ ${ }^{2}$, A. NEČAS ${ }^{2}$, T. FICHTEL 2 \\ ${ }^{1}$ Department of Diagnostic Imaging, Small Animal Clinic, University of Veterinary \\ and Pharmaceutical Sciences, Brno, Czech Republic \\ ${ }^{2}$ Department of Surgery and Orthopedics, Small Animal Clinic, University of Veterinary \\ and Pharmaceutical Sciences, Brno, Czech Republic
}

Received November 12, 2004

Accepted November 10, 2005

\begin{abstract}
Zatloukal J., M. Crha, L. Lexmaulová, A. Nečas, T. Fichtel: Gastric DilatationVolvulus Syndrom: Outcome and Factors Associated with Perioperative Mortality. Acta Vet. Brno 2005, 74: 621-631.

Gastric dilatation-volvulus (GDV) or gastric dilatation (GD), were diagnosed in 173 dogs during the period from 1997 to 2001 . Risk factors possibly associated with higher mortality in cases of GDV were evaluated. Variables suitable for quantitative evaluation were examined by the Student's $t$ - test with regard to the risk of death. We characterised groups of dogs with potential risk factors (age, body weight, time lapsed from the last feeding until presentation, time lapsed from the onset of clinical signs until presentation, time lapsed from the last feeding until the onset of clinical signs), and compared the groups with regard to the risk of death, using the $\chi^{2}$ - test. There were no differences between the dying and surviving patients as to their age, body weight and time lapsed from the last feeding until the onset of clinical signs. The time lapsed from the onset of clinical signs until presentation at the clinic was a significant factor associated with a lower survival rate. Mortality in dogs with GDV was $26.3 \%$ (36/137). Significantly higher mortality $(p<0.01)$ was found in dogs with gastric necrosis. Gastric necrosis in dogs with GDV is responsible for a 6.5 times higher risk of death compared to patients without gastric necrosis. There was also higher mortality in dogs after splenectomy $(p<0.05)$. Results of our study suggest that the most important prognostic factor is a timely treatment following the onset of clinical signs of GDV.
\end{abstract}

Dog, retrospective study, gastric necrosis, splenectomy, risk factors, feeding

Gastric dilatation-volvulus (GDV) is a very serious, life-threatening syndrome typically affecting large and giant breeds of dogs. For example, in the United States of America this syndrome affects about 60000 dogs a year (Burrows and Ignaszewski 1990). The risk of this syndrome in some dog breeds is very high. In the Great Dane it amounts to more than $40 \%$ (Glickman et al. 2000). Despite its recognition more than 90 years ago (Cadeac 1906) and considerable advances in diagnosis and treatment, mortality associated with GDV still remains high. Various studies report mortality varying from 10 to 60\% (Betts et al. 1974; Muir 1982; Walshaw and Johnson 1976; Matthiesen 1983; Frankquist and Obel 1979; Winfgield et al. 1975; Glickman et al. 1994; Brockman et al. 1995; Brourman 1996; Van Sluijs 1991; Glickman et al. 1998; Eggertsdóttir and Moe 1995; Nagel and Neumann 1992). It is, however, difficult to compare individual results because of differences in the definition of mortality and different therapeutic procedures within individual studies.

On the basis of our current knowledge, therapy of the syndrome consists of three important parts:

1) immediate and aggressive patient stabilisation including gastric decompression and treatment of shock; 2) surgical correction of volvulus including gastropexy to prevent recurrence; and 3) post-operative monitoring and intensive care (Matthiesen 1983; Aronson et al. 2000). 
Recently, a number of factors have been identified in association with higher mortality, such as mobility of the patient, patient behaviour (Glickman et al. 1998; Van Sluijs 1991) and gastric necrosis (Glickman et al. 1998; Brockman et al. 1995; Brourman et al. 1996; Matthiesen 1983).

The aim of this retrospective study was to evaluate the risk factors associated with higher mortality.

\section{Materials and Methods}

Our study comprised all dogs diagnosed with gastric dilatation (GD) or gastric dilatation-volvulus (GDV) treated at the Small Animal Clinic of the University of Veterinary and Pharmaceutical Sciences, Brno, Czech Republic, between 1997 and 2001. The analysis was based on the records of individual dogs.

Criteria for including dogs into groups of GD or GDV were based on clinical and radiographic examinations. Dogs that died before presentation at the clinic were excluded from the study. Laparotomy was performed with the consent of the owners to confirm the diagnosis of volvulus in all the cases diagnosed with GDV. When the owners refused the surgery or the dog died before surgery, the final diagnosis was made at autopsy. When the owners refused autopsy, the clinical diagnosis of GDV was considered definitive for the purposes of this study. In one dog suffering from recurrent dilatation, the diagnosis of simple gastric dilatation without volvulus was confirmed by laparotomy. In other cases of GD, the presumptive diagnosis was confirmed by repeated examinations of the patient.

The analysed data on every patient included the date of presentation, age, body weight, sex, address of the owner, time lapsed from the last feeding, time of the onset of clinical signs, and time of presentation at the clinic. The lastmentioned data, however, were not recorded in all patients. In patients undergoing surgery, other indices such as gastric necrosis, splenectomy, gastrotomy and gastrectomy were also recorded.

Patients were subjected to routine physical examination. Typical signs of GDV or GD led to an immediate treatment. It consisted of treatment of shock, gastric decompression, and gastric reposition in cases of GDV. Vascular access was obtained by placing an intravenous catheter into v. cava cranialis or v. cephalica antebrachii. Following the catheter placement, balanced complete isotonic infusion fluids (Ringer's lactate solution) were administered at $40-90 \mathrm{ml}$ per kilogram of body weight and hour. Then, a stomach tube was passed and the stomach emptied by careful compression. The stomach was rinsed repeatedly by lukewarm tap water. When it was not possible to pass a stomach tube, percutaneous gastrocentesis was performed. After the successful passage of a stomach tube, we differentiated between GD and GDV by radiography using a laterolateral projection with the animal in right lateral recumbency, and other projections in questionable cases. Patients with GDV were then treated surgically. Surgery followed patient stabilisation, judged by normalisation of the capillary refill time, colour of mucous membranes, quality of pulse and decrease in the heart rate after about 20-120 minutes from the beginning of therapy. A standard midline celiotomy was performed and the stomach repositioned to normal. When reposition was difficult due to gastric dilation, the stomach was first decompressed and then repositioned. After reposition, the gastric wall was inspected and the stomach repeatedly flushed by an orogastric tube, unless it had been done before surgery. The colour of a necrotic gastric wall remained dark red to black, particularly at the gastric fundus. The necrotic part of the stomach was resected until subjectively healthy tissue was found. Total splenectomy was performed in cases of thrombosis of $\mathrm{v}$. lienalis or its branches, avulsion or thrombosis of short gastric vessels, and spleen rupture or torsion. Incision or belt-loop gastropexy was performed in all cases to prevent recurrence.

Intravenous fluids were continued throughout the operation as well as after. Antimicrobial agents used covered Gram-negative bacteria, in particular. $\mathrm{H}_{2}$-blockers were administered intravenously in the peri-(or pre)operative period as well as post-operatively for the next 5 to 10 days. Water was offered per os 12 to 24 hours after surgery and intravenous fluid therapy was discontinued 24 to 36 hours later if no subsequent vomiting occurred after water intake. Gruel feeds in small doses should be given to patients that drink and do not vomit after gastrectomy after at least 2 days post op. Patients were monitored for cardiac arrhythmias, but infrequent extrasystoles were not treated. Cases of clinically manifested ventricular arrhythmia were treated with lidocaine in a continuous rate infusion at the dose of $25-80 \mu \mathrm{g} / \mathrm{kg} / \mathrm{min}$. Patients tolerating administration of drugs per os were given procainamide at the dose of $10-20 \mu \mathrm{g} / \mathrm{kg}$ q.i.d.

In general, we evaluated mortality and its causes in GD and GDV. In cases of GDV, we evaluated factors based on recorded data, which might be associated with higher mortality.

Variables suitable for a quantitative evaluation were examined by the Student's t-test with regard to the risk of death (age, body weight, time lapsed from the last feeding until presentation, time lapsed from the onset of clinical signs until presentation, time lapsed from the last feeding until the onset of clinical signs). For each of the potential risk factors we characterised groups of dogs to compare with each other by the $\chi^{2}$-test with regard to the risk of death. The difference between individual groups was considered to be significant at $p<0.05$. Odds ratio indicated the probability of death as compared to the control group. Values higher than or lower than 1.00 indicated higher or lower risks, respectively. Mortality was determined for each group. 


\section{Results}

During the study period we treated 173 dogs of GDV and GD. These patients represented a proportion of $0.95 \%$ of all the patients treated at the Department of Surgery and Orthopedics of the Small Animal Clinic.

A total of 17 patients were identified as GD. All survived the acute episode and were treated in a conservative way with only one dog undergoing laparotomy and gastropexy.

A total of 156 patients were diagnosed with GDV. Nineteen dogs were excluded from further analyses because they died immediately after arrival at the clinic (3 cases), or their owners disagreed with therapy because of unrelated diseases (mammary gland tumours, cardiomyopathy, chronic renal failure) or financial constraints. The remaining $137 \mathrm{dogs}$ underwent surgery after stabilisation. Three patients died during the operation. Nine other dogs were euthanized during the operation with the consent of the owner because of extensive gastric necrosis. Further 21 dogs died after the operation due to various causes (disseminated intravascular coagulopathy, circulatory collapse, heart arrest or arrhythmia). Another three patients were euthanized because of financial constraints, gastric atony and acute hepatic failure accompanied by hepatoencephalopathy. The remaining 101 patients were clinically healthy within 10-14 days after the operation.

Table 1

\begin{tabular}{|l|c|c|c|}
\hline Risk Factor & Number & Mean & Standard deviation \\
\hline Age & 36 & 7.17 & 2.97 \\
\hline Dogs died & 101 & 6.44 & 2.73 \\
\hline Dogs survived & 36 & 39.89 & 11.15 \\
\hline Body Weight & 101 & 43.14 & 13.71 \\
\hline Dogs died & \multicolumn{3}{|l|}{} \\
\hline Dogs survived & 9.54 & 6.00 \\
\hline Time Lapsed from Feeding until Initiation of Treatment $\uparrow$ \\
\hline Dogs died & 25 & 6.76 & 5.46 \\
\hline Dogs survived & 82 & 5.12 & 4.12 \\
\hline Time Lapsed from Onset of Clinical Signs until Initiation of Treatment $\uparrow$ & 3.12 \\
\hline Dogs died & 25 & 3.24 & 3.99 \\
\hline Dogs survived & 82 & 4.41 & 3.80 \\
\hline Time Lapsed from Feeding until Onset of Clinical Signs \\
\hline Dogs died & 23 & 3.50 & \\
\hline Dogs survived & 8 &
\end{tabular}

$\uparrow$ difference at level of significance $5 \%$ between dogs that died and survived (Student's $t$-test)

Risk factors, which might be associated with higher mortality in cases of GDV, are summarised in Table 1. Time periods lapsed from the last feeding until presentation and from the onset of clinical signs until presentation were considerably longer with statistical significance in patients that died than those that survived (Student's t-test, $p<0.05$ ). There were no differences between the dying and surviving patients as to their age, body weight and time period from the last feeding until the onset of clinical signs. The survival rate of dogs with GDV was not dependent on age, body weight, sex, address of the owner, or date of treatment (cf. Table 2). However, we did note a tendency to higher mortality in older dogs. Nine-year-old dogs and older had an up to 4.00 times lower survival rate than dogs under 4 years. The time lapsed from the onset of clinical signs until presentation at the clinic was a significant factor associated with a lower survival rate. Even though the time lapsed from feeding until presentation at the clinic was not a significant factor, as the interval grew, 
Table 2

\begin{tabular}{|c|c|c|c|c|c|}
\hline Risk Factor & $\begin{array}{l}\text { Number of } \\
\text { Dogs Died }\end{array}$ & $\begin{array}{c}\text { Number of } \\
\text { Dogs Survived }\end{array}$ & Odds Ratio & $\begin{array}{c}\text { Probability } \\
\text { Values }\left(\chi^{2}-\text { test }\right)\end{array}$ & $\begin{array}{c}\text { Mortality in the } \\
\text { Group of Dogs (\%) }\end{array}$ \\
\hline \multicolumn{6}{|l|}{ Age } \\
\hline$<4$ years $\mathbf{\square}$ & 3 & 18 & NA & NA & 14.29 \\
\hline $4-6.9$ years & 14 & 39 & 2.15 & NS & 26.42 \\
\hline $7-8.9$ years & 9 & 29 & 1.86 & NS & 23.68 \\
\hline$\geq 9$ years & 10 & 15 & 4.00 & NS & 40.00 \\
\hline \multicolumn{6}{|l|}{ Body Weight } \\
\hline$\leq 27 \mathrm{~kg}$ & 4 & 10 & NA & NA & 28.57 \\
\hline $28-35 \mathrm{~kg}$ & 12 & 30 & 1.00 & NS & 28.57 \\
\hline $36-47 \mathrm{~kg}$ 口 & 12 & 26 & 1.15 & NS & 31.57 \\
\hline$\geq 48 \mathrm{~kg}$ & 8 & 35 & 0.57 & NS & 18.60 \\
\hline \multicolumn{6}{|l|}{ Sex } \\
\hline Female $\mathbf{a}$ & 17 & 53 & NA & NA & 24.29 \\
\hline Male & 19 & 48 & 1.23 & NS & 28.36 \\
\hline \multicolumn{6}{|l|}{ Owner's Address } \\
\hline Local & 12 & 50 & NA & NA & 19.35 \\
\hline $\begin{array}{l}\text { From neighbouring } \\
\text { cities and villages }\end{array}$ & 24 & 51 & 1.96 & NS & 32.00 \\
\hline \multicolumn{6}{|l|}{ Year of Treatment } \\
\hline $1997 \mathbf{\square}$ & 5 & 13 & NA & NA & 27.78 \\
\hline 1998 & 4 & 27 & 0.39 & NS & 12.90 \\
\hline 1999 & 7 & 20 & 0.91 & NS & 25.93 \\
\hline 2000 & 14 & 19 & 1.92 & NS & 42.42 \\
\hline 2001 & 6 & 22 & 0.71 & NS & 21.43 \\
\hline \multicolumn{6}{|l|}{ Surgeon Number } \\
\hline $1 \mathbf{a}$ & 6 & 17 & NA & NA & 26.09 \\
\hline 2 & 1 & 4 & 0.71 & NS & 20.00 \\
\hline 3 & 2 & 8 & 0.71 & NS & 20.00 \\
\hline 4 & 9 & 10 & 2.55 & NS & 47.37 \\
\hline 5 & 1 & 5 & 0.57 & NS & 16.67 \\
\hline 6 & 3 & 9 & 0.94 & NS & 25.00 \\
\hline 7 & 0 & 6 & NA & NS & 0.00 \\
\hline 8 & 3 & 5 & 1.70 & NS & 37.50 \\
\hline 9 & 3 & 10 & 0.85 & NS & 23.08 \\
\hline 10 & 0 & 6 & NA & NS & 0.00 \\
\hline 11 & 4 & 6 & 1.89 & NS & 40.00 \\
\hline 12 & 1 & 8 & 0.35 & NS & 12.50 \\
\hline Missing data & 3 & 7 & - & - & - \\
\hline \multicolumn{6}{|c|}{ Time Lapsed from Feeding until Initiation of Treatment } \\
\hline $0-2.9 \mathrm{~h}$ & 2 & 21 & NA & NA & 8.70 \\
\hline $3-4.9 \mathrm{~h}$ & 5 & 19 & 2.76 & NS & 20.83 \\
\hline $5-10.9 \mathrm{~h}$ & 9 & 22 & 4.30 & NS & 29.03 \\
\hline$\geq 11 \mathrm{~h}$ & 9 & 20 & 4.73 & NS & 31.03 \\
\hline Data Missing & 11 & 20 & - & - & - \\
\hline \multicolumn{6}{|c|}{ Time Lapsed from Onset of Clinical Signs until Initiation of Treatment } \\
\hline $0-2.9 \mathrm{~h}$ & 8 & 47 & NA & NA & 14.55 \\
\hline $3-4.9 \mathrm{~h}$ & 7 & 21 & 1.96 & NS & 25.00 \\
\hline $5-10.9 \mathrm{~h}$ & 7 & 12 & 3.48 & $\mathrm{p}<0.05$ & 36.84 \\
\hline
\end{tabular}

- Reference category NA Not applicable NS Non-significant 
Table 2 continued

\begin{tabular}{|c|c|c|c|c|c|}
\hline Risk Factor & $\begin{array}{l}\text { Number of } \\
\text { Dogs Died }\end{array}$ & $\begin{array}{c}\text { Number of } \\
\text { Dogs Survived }\end{array}$ & Odds Ratio & $\begin{array}{c}\text { Probability } \\
\text { Values }\left(\chi^{2}-\text { test }\right)\end{array}$ & $\begin{array}{c}\text { Mortality in the } \\
\text { Group of Dogs (\%) }\end{array}$ \\
\hline$\geq 11 \mathrm{~h}$ & 3 & 2 & 8.81 & $\mathrm{p}<0.05$ & 60.00 \\
\hline Data Missing & 11 & 19 & - & - & - \\
\hline \multicolumn{6}{|c|}{ Time Lapsed from Feeding until Onset of Clinical Signs } \\
\hline $0-2.9 \mathrm{~h} \mathbf{\square}$ & 9 & 45 & NA & NA & 16.67 \\
\hline $3-4.9 \mathrm{~h}$ & 7 & 13 & 2.69 & NS & 35.00 \\
\hline $5-10.9 h$ & 6 & 15 & 2.00 & NS & 28.57 \\
\hline$\geq 11 \mathrm{~h}$ & 1 & 7 & 0.71 & NS & 12.50 \\
\hline Data Missing & 13 & 21 & - & - & - \\
\hline \multicolumn{6}{|c|}{ Gastric Necrosis } \\
\hline No $\mathbf{a}$ & 21 & 91 & $\mathrm{NA}$ & NA & 18.75 \\
\hline Yes & 15 & 10 & 6.50 & $\mathrm{p}<0.01$ & 60.00 \\
\hline \multicolumn{6}{|l|}{ Gastrectomy } \\
\hline No & 20 & 91 & NA & NA & 18.02 \\
\hline Yes & 4 & 10 & 1.82 & NS & 28.57 \\
\hline \multicolumn{6}{|l|}{ Gastrotomy } \\
\hline No $\square$ & 20 & 94 & NA & NA & 17.54 \\
\hline Yes & 4 & 7 & 2.69 & NS & 36.36 \\
\hline \multicolumn{6}{|l|}{ Splenectomy } \\
\hline No $\mathbf{a}$ & 6 & 51 & NA & NA & 10.53 \\
\hline Yes & 18 & 50 & 3.06 & $\mathrm{p}<0.05$ & 26.47 \\
\hline
\end{tabular}

- Reference category NA Not applicable NS Non-significant

mortality increased many times. Significantly higher mortality $(p<0.01)$ was detected in dogs with gastric necrosis. However, if they were treated by gastrectomy and not euthanized, gastric necrosis was no more associated with higher mortality. Higher mortality was also found in dogs that were splenectomised $(p<0.05)$. Gastrotomy or the operating surgeon had no effect on the survival rate.

Table 3

\begin{tabular}{|l|c|c|c|c|}
\hline $\begin{array}{l}\text { Time Lapsed from } \\
\text { Onset of Clinical } \\
\text { Signs until } \\
\text { Initiation } \\
\text { of Treatment }\end{array}$ & $\begin{array}{c}\text { Number of Dogs } \\
\text { with Gastric } \\
\text { Necrocis } \\
\text { (died/all cases) }\end{array}$ & $\begin{array}{c}\text { Number of Dogs } \\
\text { without Gastric } \\
\text { Necrocis } \\
\text { (died/all cases) }\end{array}$ & Odds Ratio & $\begin{array}{c}\text { Probability } \\
\text { Values }\left(\chi^{2}-\text { test) }\right.\end{array}$ \\
\hline $0-2.9 \mathrm{~h}$ & $2 / 3$ & $6 / 52$ & NA & NA \\
\hline $3-4.9 \mathrm{~h}$ & $4 / 7$ & $3 / 18$ & 5.78 & $p<0.01$ \\
\hline $5-10.9 \mathrm{~h}$ & $4 / 9$ & $3 / 10$ & 15.60 & NA \\
\hline$\geq 11 \mathrm{~h}$ & $0 / 0$ & $3 / 5$ & NA & - \\
\hline Data Missing & $5 / 6$ & $6 / 24$ & - & \\
\hline
\end{tabular}

- Reference category NA Not applicable NS Non-significant

As the duration of clinical signs increased, the number of dogs suffering from gastric necrosis and requiring splenectomy (Tables 3 and 4) became significantly higher. The number of splenectomised patients, however, did not increase significantly in dogs with gastric necrosis (Table 5). 
Table 4

\begin{tabular}{|l|c|c|c|c|}
\hline $\begin{array}{l}\text { Time Lapsed from } \\
\text { Onset of Clinical } \\
\text { Signs until } \\
\text { Initiation } \\
\text { of Treatment }\end{array}$ & $\begin{array}{c}\text { Number of Dogs } \\
\text { with Splenectomy } \\
\text { (died/all cases) }\end{array}$ & $\begin{array}{c}\text { Number of Dogs } \\
\text { without Splenectomy } \\
\text { (died/all cases) }\end{array}$ & Odds Ratio & $\begin{array}{c}\text { Probability } \\
\text { Values }\left(\chi^{2}-\text { test) }\right.\end{array}$ \\
\hline $0-2.9 \mathrm{~h}$ 口 & $3 / 26$ & $3 / 27$ & $\mathrm{NA}$ & $\mathrm{NA}$ \\
\hline $3-4.9 \mathrm{~h}$ & $4 / 10$ & $0 / 14$ & 0.74 & $\mathrm{NS}$ \\
\hline $5-10.9 \mathrm{~h}$ & $4 / 13$ & $0 / 3$ & 4.50 & $\mathrm{p}$ \\
\hline$\geq 11 \mathrm{~h}$ & $3 / 5$ & $0 / 0$ & $\mathrm{NA}$ & $\mathrm{NA}$ \\
\hline Data Missing & $4 / 10$ & $3 / 16$ & - & - \\
\hline
\end{tabular}

- Reference category NA Not applicable NS Non-significant

Table 5

\begin{tabular}{|c|c|c|c|c|}
\hline Splenectomy & $\begin{array}{l}\text { Number of Dogs } \\
\text { with Gastric } \\
\text { Necrosis } \\
\text { (died/all cases) }\end{array}$ & $\begin{array}{c}\text { Number of Dogs } \\
\text { without Gastric } \\
\text { Necrosis } \\
\text { (died/all cases) }\end{array}$ & Odds Ratio & $\begin{array}{c}\text { Probability } \\
\text { Values }\left(\chi^{2}-\text { test }\right)\end{array}$ \\
\hline No & $9 / 11$ & $7 / 56$ & NA & NA \\
\hline Yes & $6 / 14$ & $14 / 56$ & 1.27 & NS \\
\hline
\end{tabular}

- Reference category NA Not applicable NS Non-significant

\section{Discussion}

The total of 173 patients with GDV and GD represented a proportion of $0.93 \%$ of all patients treated during the study period at the Department of Surgery and Orthopedics of the Small Animal Clinic. The possibility of comparing our findings with published data on the prevalence of GD and GDV is rather limited, because our study was based on patients treated at the Department of Surgery only, while other studies included all the patients at a clinic. The system of administration and data recording at other departments did not allow such evaluation. Dogs with GDV and GD represented approximately 0.3 to $0.4 \%$ of all the patients treated at our Small Animal Clinic. This prevalence of the syndrome corresponds with other studies reporting the range of 0.13 to $0.76 \%$ of all the patients treated (Strombeck and Guilford 1990; Glickman et al. 1994).

According to previous studies, 22 to $48 \%$ of patients with a bloat syndrome suffered from GD (Brockman et al. 1995; Glickman et al. 1994). In our study, there were only about $10 \%$ of patients with GD. This might be because of an actually lower prevalence of simple gastric dilatation in the Czech Republic, or due to the pre-selection of patients at other departments of the Small Animal Clinic by referring veterinary surgeons. Another possible explanation is that some cases presented in this study had a relatively long time period from the onset of clinical signs until presentation at the clinic. Most authors share the opinion that in the GDV syndrome, gastric dilatation occurs as a primary event, whereas volvulus occurs secondarily (Matthiesen 1993; Aronson et al. 2000). The longer time lapsed from the onset of clinical signs until arrival at the clinic could thus be responsible for the change from simple dilatation to secondary volvulus of the presented case.

Patients with GD had a $100 \%$ survival rate (17/17). This corresponds to the study by Brockman et al. (1995), documenting an approximately $99 \%$ survival rate in dogs with GD. Since our clinic employs a similar therapeutic scheme as was used in the above mentioned study, it may be assumed that GD patients treated with this method have an 
excellent prognosis. Results of these clinical case studies could thus confirm that in GDV patients, volvulus is a much more important factor, leading to gastric necrosis, considerable alteration of the general condition of the patient, and higher mortality. However, the question remains as to the relatively low survival rate of patients with GD recorded in the Veterinary Medical Data Base at 12 veterinary institutions from 1980 to 1989 . These patients had $28.6 \%$ mortality (Glickman et al. 1994). Perhaps the difference may be due to different therapeutic procedures or improper selection of cases.

It is difficult to compare the mortality of our GDV patients with the published data because of different definitions of mortality, therapeutic procedures and equipment of individual clinics. In our study we found a $26.3 \%$ (36/137) mortality of dogs with GDV. Some authors, however, include all patients into the computation of the survival rate. In that case our study should include the patients euthanized after diagnosis due to unacceptable financial costs or concurrent diseases (16 cases), and the patients dying immediately after arrival at the clinic (3 cases). Such mortality would amount to $35.3 \%$. Compared to the published data, our $26.3 \%$ mortality was similar or slightly less successful than the results obtained by specialised or university clinics with mortality rates of $13.2 \%$ (Glickman et al. 1998), 13.9\% (de Papp et al. 1999), 15\% (Brockman et al. 1995), 17.5\% (Brourman et al. 1996), 29\% (Van Sluijs 1991), 33.3\% (Glickman et al. 1994), 33.2\% (Nagel and Neumann 1992), 33.3\% (Matthiesen 1983), 34\% (Eggertsdóttir and Moe 1995), $34.1 \%$ (Flanders and Harvey 1984). Differences in survival rates among individual clinics using similar procedures can be due to various levels of pre- and early post-operative care and patient monitoring that allows decreasing the early post-operative mortality by quick and aimed therapy. Such care was not possible at our clinic for patients presenting with GDV and GD overnight due to the lack of most laboratory examinations and personnel. In order to decrease mortality in these cases, it seems inevitable to create an independent intensive care unit of sufficient equipment and competent personnel. At present, however, the survival rate is considerably influenced by early treatment, which depends on adequate public awareness of the syndrome.

A number of factors which might be associated with higher mortality in dogs with GDV (Glickman et al. 1998; van Sluij s 1991; Brockman et al. 1995; Brourman et al. 1996; Matthiesen 1983) have already been studied. As Brockman et al. (1995), we did not include the dogs euthanized after diagnosis or dying on arrival at the clinic into the analysis of factors increasing mortality. It seems more appropriate to exclude these patients from the study (29 cases euthanized before surgery), because it is not clear whether they would have survived or died after treatment. For this reason, the results of the study by Glickman et al. (1998) must be considered with care; they included this kind of patients into the group of dead dogs, which might lead to misrepresentation.

The age of the dog suffering from the GDV syndrome is one of the potential risk factors. In our study, we did not find older age of the dog to be a significant risk factor for the shortterm survival rate. Nevertheless, patients that did not survive were older on average than the surviving ones, and 9-year-old patients or older had a 4.00 times higher mortality than dogs under 4 years. Glickman et al. (1998) report similar values and found a 3.11 times higher risk for the same age categories. The cause of this phenomenon remains unexplained. Changes of the cardiovascular apparatus in the form of sub-clinical disorders or age-related lesions leading to the loss of compensation mechanisms may play a role.

The age and sex of the dogs in our study as well as in others (Glickman et al. 1998; van Sluijs 1991; Brockman et al. 1995; Brourman et al. 1996; Matthiesen 1983) did not influence the survival rate. The lower risk of death in dogs weighing $48 \mathrm{~kg}$ or more found in our study might be explained by greater awareness of the risk of GDV among the owners of giant breeds, and by the resulting earlier arrival at the clinic after the onset of clinical signs. 
Time lapsed from the onset of clinical signs until presentation of the patient and from the last feeding until presentation was a significant risk factor for the survival rate in our study. The time lapsed from the last feeding until presentation is a sum of time periods lapsed from the last feeding until the onset of clinical signs and from the onset of clinical signs until presentation. As the time lapsed from the last feeding until the onset of clinical signs is not a significant factor, the only risk factor is the time period from the onset of clinical signs until presentation. Dogs with GDV arriving at the clinic within three hours from the onset of clinical signs had a nine times lower mortality rate than those arriving after eleven and more hours. Our study thus confirms the general recommendation to treat such patients as soon as possible after the onset of clinical signs (Arons on et al. 2000; Strombeck and Guilford 1990). Previous studies, however, did not strictly determine the time period from the onset of clinical signs until presentation as a significant risk factor (Glickman et al. 1998; Van Sluijs 1991; Brockman et al. 1995). Van Sluijs (thesis) found that in a proportion of dogs, GDV can have a very quick progress and high mortality, associated with a marked and quick onset of signs, whereas in other cases the syndrome can have lower mortality with a slow onset of clinical signs, which allows the owners to arrive at the clinic much later. For purposes of future studies it would therefore be appropriate to consider other factors possibly influencing mortality, such as the degree of volvulus and gastric distension. It is interesting to compare our survival rate with the values published by Glickman et al. (1998) in relation to the time lapsed from the onset of clinical signs until presentation. In our study, dogs treated within two hours from the onset of clinical signs are characterised by $14 \%$ mortality (8/55), whereas in the study by Glickman et al. (1998) it is $20 \%(14 / 70)$. The difference in the total survival rates between these two studies depends only on the duration of clinical signs before treatment. Patients in our study arrived and received treatment later. Dog owners' awareness of clinical signs and urgency of treatment, not only in the predisposed breeds, along with a better pre- and post-operative care could contribute to higher survival rates of GDV patients. A number of owners, however, do not have their dog under supervision after feeding. In such dogs the time lapsed from the last feeding until presentation could serve as a prognostic criterion.

Gastric necrosis was a highly significant risk factor in our study $(p<0.01)$. Gastric necrosis in dogs with GDV is responsible for a 6.5 times higher risk of death, compared to patients without gastric necrosis. Mortality in such patients amounts to $60 \%$. These results correspond to other studies reporting gastric necrosis as a significant risk factor with mortality rates as high as 60\% (Van Sluijs 1991; Glickman et al. 1998; Brockman et al. 1995; Brourman et al. 1996; Clark and Pavletick 1991). As in other papers, gastric necrosis was the most common reason for patient euthanasia in our study. An interesting finding is that, if patients are left alive during the operation despite gastric necrosis and go through gastrectomy, gastric necrosis becomes an insignificant risk factor and mortality in such patients amounts to about $28 \%$, a value only twice as high as in the patients not requiring gastrectomy. This result leads us to believe that patients with gastric necrosis are euthanized too soon and might survive after gastrectomy. However, the term gastric necrosis is quite general and can mean the affection of only a small part of fundus or the whole gastric wall. It would therefore be appropriate for further studies to specify the extent of gastric necrosis before conclusions about the relationship between gastrectomy and survival in cases of gastric necrosis can be made.

The number of dogs with gastric necrosis in our study significantly increased with the duration of clinical signs. Gastric necrosis was found in 5.5, 24.1 and 47.4\% of dogs treated within three hours, after 3 to 4.9 hours and 5 to 10.9 hours from the onset of clinical signs, respectively. Our results of clinical cases confirm previous experimental studies of surgically induced gastric volvulus, in which necrotic changes of gastric fundus were found 
after 4 hours (Lantz et al. 1984). In five patients suffering from clinical signs for 11 hours and more, there was no gastric necrosis. In spite of it, three of them died. In our opinion, the absence of gastric necrosis in dogs with ongoing clinical signs for 11 hours and more is simply caused by the fact that dogs suffering from GDV including gastric necrosis would not live long enough to receive treatment.

As in a previous study (Brourman et al. 1996), splenectomy was another risk factor associated with higher mortality. In the GDV syndrome, splenomegaly is commonly caused by congestion of the spleen due to hypertension of vena portae and a. lienalis, or strangulation of vena lienalis secondary to splenic torsion. Long-lasting congestion of the spleen (particularly in spleen torsion) leads to marked systemic hypovolemia, ischemia and subsequent necrosis of spleen parenchyma. It results in the thrombosis of vessels in the spleen and possibly in systemic thromboembolism and development of DIC (Pope and R oc hat 1993). If necrosis of the spleen (dark blue or even black colour) or thrombotisation of large vessels become evident, the spleen should not be repositioned but removed because of the possibility of releasing vasoactive mediators, micro-thrombi or degradation products into the systemic circulation (Matthiesen 1993; Aronson et al. 2000). When splenectomy is performed in cases not requiring the procedure, the animal gets stressed by the loss of red blood cells, thrombocytes and some coagulation factors. In this way, splenectomy could initiate the onset of DIC, hypovolemia, shock progression and the loss of compensation mechanisms of the cardiovascular apparatus. It was also found that splenectomy by itself can be the cause of ventricular arrhythmia (Marino et al. 1994). Splenectomy also significantly prolongs the operation. Higher mortality associated with splenectomy could be caused both by disorders of the spleen and the splenectomy itself. The decision to perform splenectomy is thus quite controversial. Matthies en (1983), MayerLindenberg et al. (1993) and Brockman et al. (1995) report splenectomy in 8, 3.4 and $20.2 \%$ of dogs with GDV, respectively. In comparison to the above mentioned studies, we performed splenectomy much more often, i.e. in $53.1 \%$ of the operated dogs (68/125). It is questionable whether it was necessary in all the cases, and whether preservation of the spleen might have increased the survival rate.

Splenectomy in our study was performed more often in dogs with a longer duration of clinical signs of GDV. In dogs treated within three hours, after 3 to 4.9 hours, 5 to 10.9 hours and 11 hours and more from the onset of clinical signs, splenectomy was performed in 49.1 , $41.7,81.3$ and $100 \%$ of cases, respectively. It confirms the fact that some time is necessary for the pathology of the spleen to develop. We did not, however, find any association between gastric necrosis and splenectomy. Since we obtained the data from patient records, it is not possible to generalise or overestimate this finding. The results may possibly be distorted by cases in which pathology of the spleen was diagnosed, but the animals were euthanized due to gastric necrosis and no splenectomy was performed.

We conclude from the results of our study, that the most important prognostic factor is a timely treatment following the onset of clinical signs of GDV. All other risk factors evaluated in this study, such as gastric necrosis and splenectomy are only a consequence of a late treatment. The duration of clinical signs can thus help to formulate a prognosis even on arrival at the clinic. When owners do not know the time of the onset of clinical signs, it is possible to use the time lapsed from the last feeding as a prognostic criterion. Other prognostic clinical signs such as mobility of the patient on arrival, patient behaviour (Glickman et al. 1998; V an Sluij s 1991), heart arrhythmia (Brourman et al. 1996) and plasma lactate level (de Papp et al. 1999) can also be employed. Our study confirmed that better awareness of GDV among the owners of giant breeds of dogs (over $48 \mathrm{~kg}$ ) led to a timely arrival at the clinic with nearly half the mortality rate in comparison to other breeds $(18.6 \%)$. It should therefore be the goal of veterinary medicine not only to provide 
continuous intensive care for dogs with GDV but also to promote public awareness among dog owners about this syndrome.

\section{Syndrom dilatace a volvulu žaludku - výsledky a faktory spojené s perioperační úmrtností}

Syndrom dilatace a volvulu žaludku: výsledky a faktory spojené s perioperační úmrtností

Dilatace a volvulus žaludku (GDV) nebo dilatace žaludku (DV) byly diagnostikovány u 173 psů během období od ledna 1997 do srpna 2001. Diskutovány jsou rizikové faktory, které mohou souviset $\mathrm{s}$ vyšší mortalitou $\mathrm{v}$ př́ípadech GDV. Parametry vhodné pro kvantitativní vyhodnocení byly zhodnoceny s ohledem na riziko úmrtí za použití Studentova t-testu. Byly stanoveny skupiny psů s možnými rizikovými faktory (stárí, tělesná hmotnost, časové období od posledního krmení do příchodu na kliniku, časové období od začátku klinických příznaků do příchodu na kliniku, časové období od posledního krmení do začátku klinických příznaků), a tyto skupiny byly porovnány s ohledem na riziko úmrtí za použití $\chi^{2}$-testu. Nebyl zjištěn rozdíl mezi uhynulými a přežívajícími pacienty s ohledem na stáří, tělesnou hmotnost a období od posledního krmení do začátku klinických př́íznakủ. Signifikantní faktor spojený s nižší mírou př̌žívání byl časový úsek do začátku klinických příznaků po příchod na kliniku. Úmrtnost u psů s GDV byla $26,3 \%$ (36/137). Signifikantně vyšší úmrtnost $(p<0,01)$ byla u psů s nekrózou žaludku. Nekróza žaludku u psů s GDV představovala 6,5krát vyšší riziko úmrtí v porovnání s pacienty bez nekrózy žaludku. Byla zjištěna také vy̌šśí úmrtnost u psů po splenektomii $(p<0,05)$. Výsledky naší studie vedou $\mathrm{k}$ závěru, že nejdůležitějším prognostickým faktorem je včasnost léčby, bezprostředně po projevení se klinických př́iznaků GDV.

\section{Acknowledgements}

This work was supported by the Ministry of Education, Youth and Sports of the Czech Republic (Research Project no. 161700002).

\section{References}

ARONSON LR, BROCKMAN DJ, BROWN DC 2000: Gastrointestinal emergencies. Vet Clin North Am Small Anim Pract 30: 555-579

BETTS CW, WINGFIELD WE, GREEN RW 1974: A retrospective study of gastric dilatation-torsion in the dog. J Small Anim Pract 15: 727-734

BROCKMAN DJ, WASHABAU RJ, DROBATZ KJ 1995: Canine gastric dilatation/volvulus syndrome in a veterinary critical care unit: 295 cases (1986-1992). J Am Vet Med Assoc 207: 460-464

BROURMAN JD, SCHERTEL ER, ALLEN DA, BIRCHARD SJ, DEHUFF WD 1996: Factors associated with perioperative mortality in dogs with surgically managed gastric dilatation-volvulus: 137 cases (1988-1993). J Am Vet Med Assoc 207: 1855-1858

CADEAC C 1906: Reduction de la torsion de l'estomac chez le chien. J Med Vet Zootechnol 57: 16-18

CLARK GN, PAVLETIC MM 1991: Partial gastrectomy with an automatic stampling instrument for treatment of gastric necrosis secondary to gastric dilatation-volvulus. Vet Surg 20: 61-68

DE PAPP E, DROBATZ KJ, HUGHES D 1999: Plasma lactate concentration as a predictor of gastric necrosis and survival among dogs with gastric dilatation-volvulus: 102 cases (1995-1998). J Am Vet Med Assoc 215: 49-52

EGGERTSDÓTTIR AV, MOE L 1995: A retrospective study of conservative treatment of gastric dilatationvolvulus in the dog. Acta Vet Scand 36: 175-184

FLANDERS JA, HARVEY HJ 1984: Results of tube gastrostomy as treatment for gastric volvulus in the dog. J Am Vet Med Assoc 185: 74-77

FRANKQUIST B, OBEL N 1979: Gastric torsion in the dog-II nonsurgical treatment by aspiration of gastric contents during repeated rotation of the animal. J Small Anim Pract 20: 93-102

GLICKMAN LT, GLICKMAN NW, PÉREZ CM, SCHELLENBERG DB, LANTZ GC 1994: Analysis of risk factors for gastric dilatation and dilatation-volvulus in dogs. J Am Vet Med Assoc 204: 1465-1471

GLICKMAN LT, GLICKMAN NW, SCHELLENBERG DB, RAGHAVAN M, LEE TL 2000: Incidence of and breed-related risk factors for gastric dilatation-volvulus in dogs. J Am Vet Med Assoc 216: 40-45 
GICKMAN LT, LANTZ GC, SCHELLENBERG DB, GLICKMAN NW 1998: A prospective study of survival and recurrence following the acute gastric dilatation-volvulus syndrome in 136 dogs. J Am Anim Hosp Assoc 34: 253-259

LANTZ GC, BOTTOMS GD, CARLTON WW, NEWMAN S, CANTWELL HD 1984: The effect of $360^{\circ}$ gastric volvulus on the blood supply of the nondistended normal dog stomach. Vet Surg 13: 189-196

MARINO DJ, MATTHIESEN DT, FOX PR., LESSER MB, STAMOULIS ME 1994: Ventricular arrythmias in dogs undergoing splenectomy: A prospective study. Vet Surg 23:101-106

MATTHIESEN DT 1993: Pathophysiology of gastric dilatation-volvulus. In: BOJRAB, MJ, SMEAK DD, BLOOMBERG MS.: Disease mechanisms in small animal surgery. Lea \& Febiger, Philadelphia, pp. 220-231

MATTHIESEN DT 1983: The gastric dilatation-volvulus complex: medical and surgical considerations. J Am Anim Hosp Assoc 19: 925-932

MAYER-LINDERBERG A, HARDER A, FEHR M, LÜERSSEN D, BRUNNBERG L 1993: Treatment of gastric dilatation-volvulus and a rapid method for prevantion of relapse in dogs: 134 cases (1988-1991). J Am Vet Med Assoc 203: 1303-1307

MUIR WW 1982: Gastric dilatation-volvulus in the dog, with emphasis on cardiac arrhythmias. J Am Vet Med Assoc 180: 739-42

NAGEL ML, NEUMANN W 1992: GDV-syndrome in the dog.2. Prakt Tierarzt 73: 871-876

POPE ER, ROCHAT MC 1993: Spleen. In: BOJRAB MJ, SMEAK DD, BLOOMBERG MS.: Disease mechanisms in small animal surgery. Lea \& Febiger, Philadelphia, pp. 616-621

STROMBECK DR, GUILFORD WG 1990: Gastric dilatations, gastric dilatations-volvulus, and chronic gastric volvulus. In: STROMBECK DR, GUILFORD WG (2nd ed.): Small animal gastroenterology. Wolfe Publishing Ltd, London, pp. 228-243

VAN SLUIJS FJ 1991: Gastric dilatation-torsion in the dog: current views and a retrospective study in 160 patients. Tijdschr Diergeneeskd 116: 112-121

WALSHAW R, JOHNSON DE 1976: Treatment of gastric dilatation-volvulus by gastric decompression and patient stabilization before major surgery. J Am Anim Hosp Assoc 12: 162-167

WINGFIELD WE, BETTS CW, GREENE RW 1975: Operative techniques and recurrence rates associated with gastric volvulus in the dog. J Small Anim Pract 16: 427-432 
